\title{
Shareholder Rights and the Importance of Foreign Shareholders
}

\author{
Christoph Van der Elst \\ Department of Business Law, CCL and TILEC \\ Tilburg University \\ FLI, Ghent University
}

January 2010

\begin{abstract}
In many countries shareholders were offered more rights to protect their position against "inappropriate" behaviour of other corporate constituents. Whether these developments resulted in more market participation and deeper and more liquid markets, as argued in law and finance theory, remained an open question. For a large sample of European listed companies we reveal part of the answer: we analyse the evolution of the investment behaviour of foreign shareholders in a large sample of European companies between 1999 and 2007.

A steadily growing number of all large stakes belong to foreign shareholders. However, the average voting block of a foreign shareholder decreased in all countries but in Germany. The results show that the hypothesis of a straightforward inverse linear relationship between shareholder rights and ownership concentration is not confirmed. Other features drive the development of ownership structures. These factors are of a legal nature, like the mandatory bid threshold, or are more shareholder specific, like the investment contraints of UCITS.
\end{abstract}

JEL Classification: G32, G34, K22.

Keywords: ownership structure, foreign shareholders, law and finance, legal regulation 
Free capital movement is one of the "four freedoms" enabling competitive financial markets. However, an open market requires the abolishment of barriers to operate abroad. In 1999, the European financial services action plan was the start to (further) reduce many barriers for European wide investing. ${ }^{1}$ It was later accompanied with a plan to modernise corporate law ${ }^{2}$, initiated by the High Level Group of Company Law Experts. Both plans resulted in a new and extensive framework for the integrated European capital market.

Many but not all results of the integration of the European capital market have been studied. $^{3}$ In this contribution I want to explore one other specific element: the development of foreign shareholders' investments in the capital of listed entities in six European countries. The first section discusses briefly the leximetrics approach of company law. In the second section the dataset and the methodology that are used in this study are presented. Section three is subdivided in two parts: an analysis of the number and classes of foreign shareholders and an examination of size of the voting blocks of foreign shareholders. Section four describes foreign ownership from a portfolio approach. Section five concludes.

\section{Leximetrics of company and securities law.}

Leximetrics quantifies law. Since the development of the "law and finance" theory, many economists and lawyers have quantified shareholder, creditor, and employees rights via an analysis of company, securities and insolvency law. Lele and Siems ${ }^{4}$ developed the widely criticised original model of La Porta and others ${ }^{5}$ with six one year "anti-director" rights and six one-year creditor rights into a model with 42 shareholder rights, which help to protect the interest of shareholders against shirking of directors and 18 minority shareholder rights, which help to protect the interest of minority shareholders against expropriation of controlling shareholders over a period of thirty-five years in five countries (US, UK, India, Germany and France). Not every right is covered, but in a diligent way they combine many pivotal rights in corporate law while taking into account considerations of contract law and civil procedure. The rights are more or less centered around the position and power of individual shareholders vis-à-vis the general meeting and vis-à-vis the powers and position of directors and boards. In light of the following analysis of ownership structures we expanded their model with Italy and Belgium for the period of 1994 and 2005. A summary of the findings is presented in figure 1 . The shareholder index shows an increase in shareholder rights in all countries. By the end of 2005 all countries offered all shareholders between 25 and 30 rights (on a scale of 42 rights). For France,

$1 \quad$ European Commission, Financial Services: Implementing the Framework for Financial Markets: Action Plan, Brussel, 11 May 1999, COM (1999) 232, 32 p.

2 European Commission, Modernising Company Law and Enhancing Corporate Governance in the European Union - A Plan to Move Forward, Brussel, 21 May 2003, COM (2003) 284, 29 p.

$3 \quad$ For a number of studies, see the European website http://ec.europa.eu/internal market/capital/reports/index en.htm (last accessed 31 January 2010).

P. Lele and M. Siems, "Shareholder Protection: A Leximetric Approach”, Journal of Corporate Law Studies 2007, 17-50.

R. La Porta, F. Lopez-de-Silanes, A. Shleifer, R. Vishny, "Legal Determinants of External Finance”, Journal of Finance 52, 1997, 1131-1150. 
Germany and Belgium the increase is statistically significant. ${ }^{6}$ The variability of the rights between the five developed countries is limited and even decreased over the years. Whilst Belgium offered less than half of the total number of rights to shareholders in 1994 and the UK already offered more than 26 rights, the difference between the best - the UK - and the worst performing country - Belgium - was less than 4 rights in 2005. The development of the minority shareholder rights index shows a different pattern. In three out of five countries, minority shareholders experienced hardly any increase in the number of the shareholder rights. In France the latest development was even negative: the quorum rules for decision making at general meetings of shareholders were softened. Acting against expropriation of large shareholders is only supported in Germany with new rights. There are no significant differences in any of the countries between 1994 and 2005. In this setting, Italy has the best formal institutional setting protecting the minority shareholders. We will discuss this finding further. ${ }^{7}$ Overall the different approach in continental Europe and in the UK is clear. In continental Europe blockholders are common. Therefore, the legislation endorsed and should endorse the protection of minority shareholders. The endorsement started already before 1995. In the UK, major blockholders are rather the exception than the rule. The UK supported the protection of shareholders against shirking of directors and management: the protection against (expropriation by) major shareholders is relatively weak developed.

Figure 1: Development of shareholder and minority shareholder rights in five European countries (1994-2005)

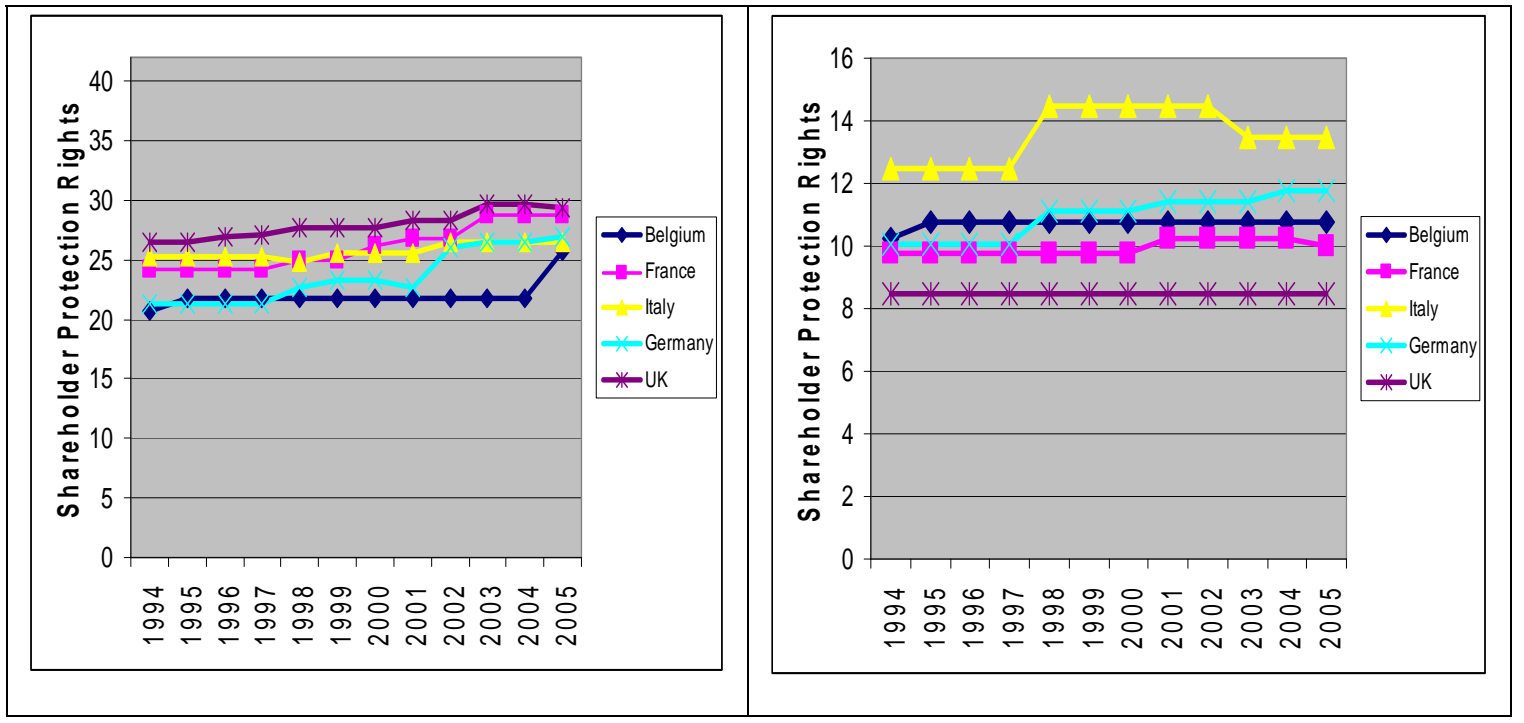

Source: France, Germany and UK: P. Lele and M. Siems, "Shareholder Protection: A Leximetric Approach”, Journal of Corporate Law Studies 2007, 17-50; Belgium and Italy: own research (for Italy research assistance was provided by Ranieri Giunta and Endrit Mema)

$6 \quad$ See for a detailed analysis of the development, C. Van der Elst, Law and Economics of Shareholder Rights and Ownership Structures: How Trivial Are Shareholder Rights for Shareholders, working paper, November 2009, 59 p.

See section 5 . 
In a "law and finance" setting the increase in the number of shareholder rights against shirking of directors suggests that the ownership concentration levels will decrease. Enhanced protection of the position of the shareholder will no longer require the same level of highly concentrated ownership as the latter is substituted by (the provision of) more shareholder rights. The insignificant increase in the number of minority shareholders rights against expropriation by controlling shareholders, implies that minority shareholders remain confronted with a significant probability of controlling shareholder expropriation. The impact of this status quo on the developments of the size of voting blocks of minority shareholders is ambiguous. It can be argued that minority shareholders will increase their voting power in order to counterbalance the position of the controlling shareholder. However, it is also possible that the minority shareholders reduce the exposure of expropriation by reducing their position in controlled companies.

The development of the ownership of foreign shareholders is studied in the next sections. As this type of shareholder must rely on the qualities of the legal system even more than national shareholders - it can be argued that they are more sensitive to formal legal developments.

\section{Data and methodology}

We have collected the voting right structure in 1999 and 2007 for a large sample of European companies listed before 1999 and until 2008. ${ }^{8}$ We opted for an identical sample in 1999 and 2008 to exclude the influence of different sample compositions. The distribution of the sample of companies in the dataset can be found in table 1 . We included Spain notwithstanding the absence of the developments of the shareholder rights of this country, because the ownership data shows some remarkable differences between this country and the five other countries. The distribution of companies of different countries is more or less similar to the importance of the different national stock markets, except for France where the number of data is smaller and biased towards larger companies. ${ }^{9}$ The average market capitalisation of the French companies is almost three times the average of the overall sample.

Table 1: Number and size of companies in the sample

Number of

Listed entities Avg. market Avg. market

in sample cap. 99 (mio.) cap 07 (mio)

$\begin{array}{lrrr}\text { France } & 95 & 10.513 & 12.375 \\ \text { Belgium } & 84 & 1.363 & 2.299 \\ \text { UK } & 272 & 3.339 & 4.209 \\ \text { Germany } & 242 & 3.971 & 3.658 \\ \text { Italy } & 114 & 3.305 & 4.558 \\ \text { Spain } & 95 & 2.694 & 5.512 \\ \text { Total } & 902 & & \end{array}$

$8 \quad$ For the UK companies, the data are from april 2001 and 2007.

9 The market capitalisation data were acquired via the different stock markets where the companies have their most important listing. 
We based our analysis on data as they have been published by individual companies and their shareholders according to the legislation that transposes the major shareholdings directive of 1988 and the transparancy directive of 2001 and 2004. Next to annual reports different databases were used: for Belgium the data were obtained from Euronext NYSE Brussels transparency declarations, for France the data that were disclosed via the website of the Autorité des Marchés Financiers (formerly $C O B$ ) are used, for Italy and Spain the information is provided by the Italian and Spanish supervisory authority Consob and Comision Nacional del Mercado de Valores, for the UK the ownership data were acquired from Hemscott and for Germany the databases of both Hoppenstadt Aktienführer and Bafin were used.

Each shareholder holding a voting block of more than 5 per cent of the voting rights ${ }^{10}$ of each company was classified in a shareholder class. The different shareholder classes that were used in all six countries are: individuals and families, non-financial companies, insurance companies, banks, the government and foreign shareholders. For the latter class, the shareholders were subdivided in identical classes as the classes used at national level. In all countries other types of shareholders exist. All these shareholders have been identified even though not all the data are presented for all these remaining shareholder classes. ${ }^{11}$

While in most cases the type of shareholder was obvious, for a significant number of shareholders different sources, including several search engines, have been used to identify the type of shareholder. In another paper on "shareholder mobility" it is illustrated how the procedure was applied. ${ }^{12}$ As the law and finance theory requires the study of the voting power, in the next section the unweighted averages will be presented.

\section{Large foreign shareholders}

\subsection{Representative classes of large foreign shareholders}

Companies experience an internationalisation of their ownership structure. Whereas the home country bias did not (yet) completely disappear, the increasing number of foreign shareholders acquiring large blocks in many European companies illustrate the decreasing importance of local investment policies. This development is more than likely due to the significant efforts of the European Union to develop an integrated capital market. In Belgium and Germany 30 per cent of all large stakes are in hands of foreign shareholders (figure 2). In France and the UK one of every four stakes belong to overseas shareholders. Southern European countries are lagging behind with 15 per cent to 20 per cent foreign blockholders. The internationalisation of the shareholder structure was remarkable in Germany and France. In Germany the

10 The lowest common threshold in all countries in both years. In the following sections these shareholders have been qualified as "large shareholders".

11 Some other important classes are (Dutch) "stichtingen administratiekantoren” in Belgium, "grouped holdings of employees" in France, "investment managers" in Germany, "investment managers”, "nominees”, and "trusts” in the UK, “fondaziona” in Italy and "fundacion” in Spain. In the UK, Germany and France national or foreign private equity funds and hedge funds are also common.

12 See section 3.2. of in the paper C. Van der Elst, Shareholder Mobility in Five European Countries, ECGI - Law Working Paper No. 104/2008. 
growth in numbers over a period of eight years was almost 300 per cent and in France the number of foreign stakes doubled. Belgium and the UK which already had a relative high number of foreign shareholders in 1999, had rather modest growth rates. Southern European countries like Italy and Spain did not develop in a similar way. Italy experienced a small increase and in Spain the number of large foreign shareholders significantly decreased. There are several elements that help to explain the relative decline. First, there was a significant increase in the number of large stakes held by Spanish shareholders, resulting in a relative decline in the number of foreign shareholders. Especially individuals and non-financial Spanish companies acquired additional stakes. Next, a number of foreign banks and foreign non-financial companies sold their stakes. For both classes of foreign shareholders, mostly smaller blocks were sold in the market. In particular American banks sold their blocks.

Figure 3 presents the allocation of large voting blocks in hands of foreign shareholders. In 1999, foreign non financial companies were the most and only important class of foreign investors in Belgium, France, Germany and Italy and the second most important class in Spain. In Spain foreign banks held more large stakes. In the UK, foreign investment funds controlled more than half of the total number of large stakes held by foreign investors. In Belgium Dutch trusts (controlled by Belgian families) are of considerable importance.

Figure 2: Relative number of large stakes $(>5 \%)$ in hands of foreign shareholders

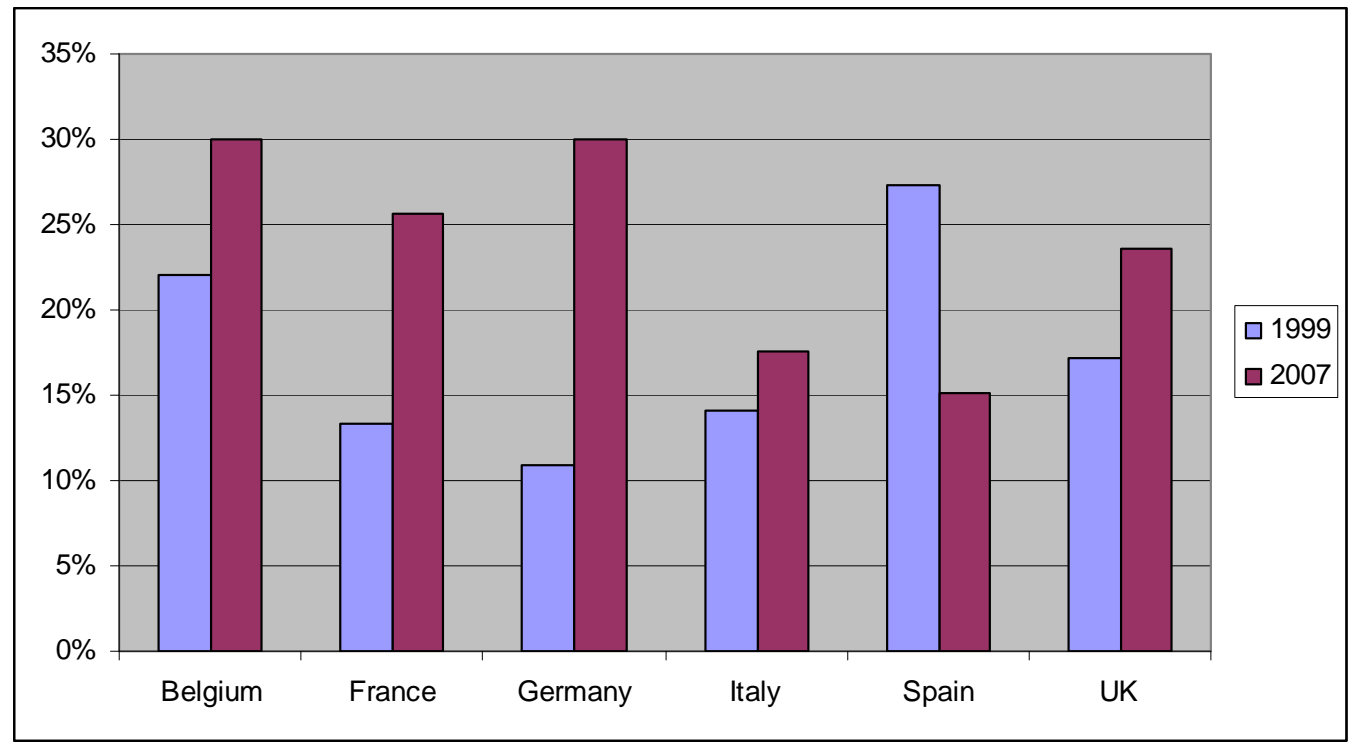

Source: own research

This pattern changed significantly in the first decade of the twenty first century. In Germany and Belgium foreign non financial shareholders remained the most important class of foreign shareholders. In 2007, 12 per cent of all German large shareholder stakes and 10 per cent of all Belgian large shareholder stakes were held by foreign non financial companies. In France and Italy, the pole position of foreign non financial companies measured in number of large stakes, is taken over by foreign investment funds, which remained the most important foreign shareholder class in the 
UK. In Spain, foreign banks and investment funds remained the most important foreign shareholder classes.

Figure 3: Importance of the different foreign shareholder classes measured by number of large stakes (1999-2007)

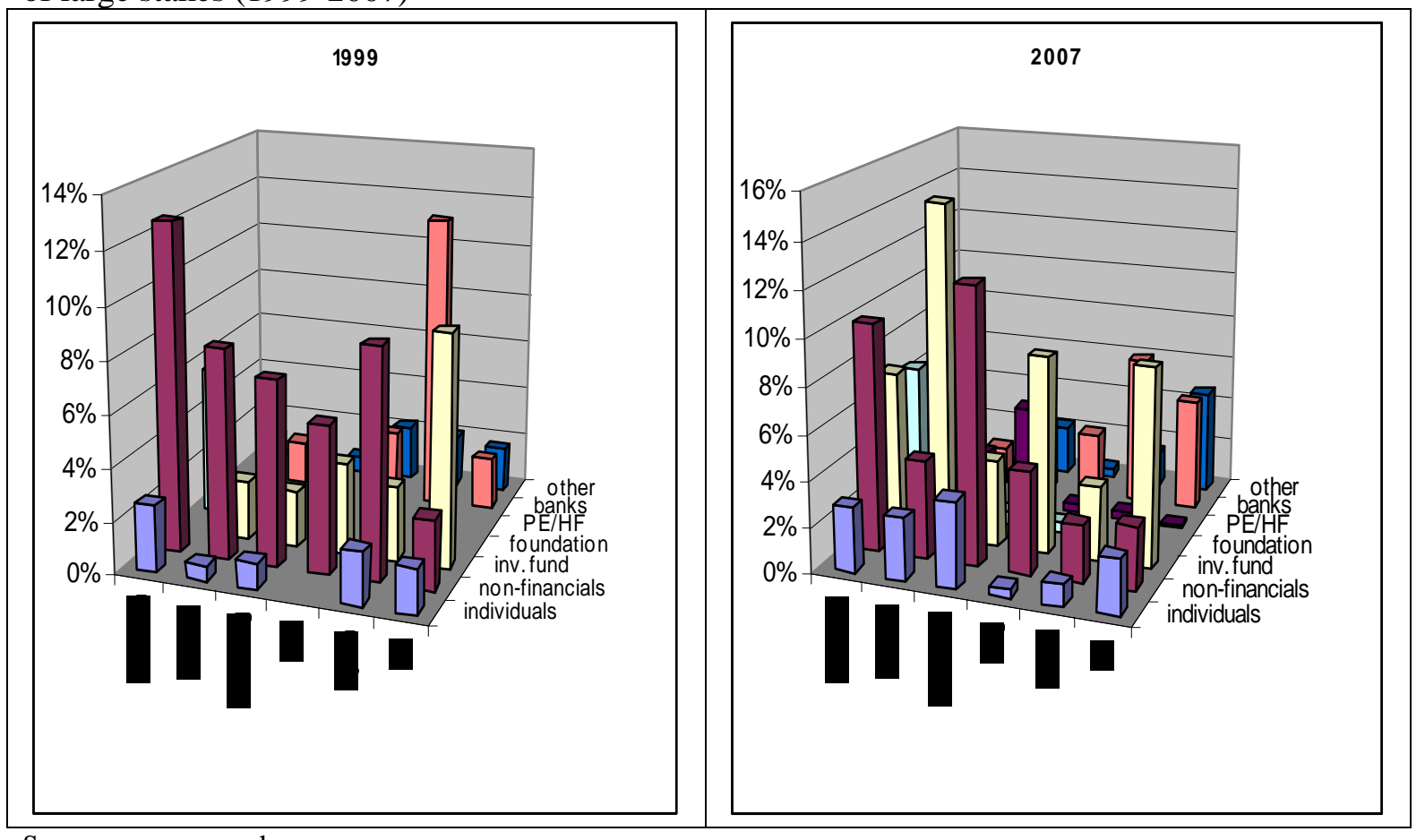

Source: own research

In French and in German companies, foreign hedge funds acquired a significant number of large stakes. This development provides an explanation as to why these two countries are standing on the barricades for a regulatory framework for these funds at the moment of writing. Finally, with the exception of Spain, all countries experienced an increase in the number of large stakes in hands of foreign banks. In the UK this number more than doubled. It can be questioned whether this development must be supported. We certainly believe that the economic and banking crisis will have brought this process to an end.

The importance of foreign ownership is also measured by the number of companies where at least one large voting block is in hands of foreign investors. Half of the companies in the UK and Belgium, 40 per cent of the companies in France and Germany and around 30 per cent of the companies in Spain and Italy have a large foreign shareholder. This evolution is similar to the evolution of the total number of foreign voting blocks: a significant increase in Belgium, France, Germany and the UK, a modest increase in Italy and a significant decrease in Spain. The results illustrate that the home biased investment did not completely disappear since in all countries at least half of the companies are unfamiliar with large foreign shareholders. 
Figure 4: Relative number of companies with at least one large foreign shareholder $(>5 \%)$

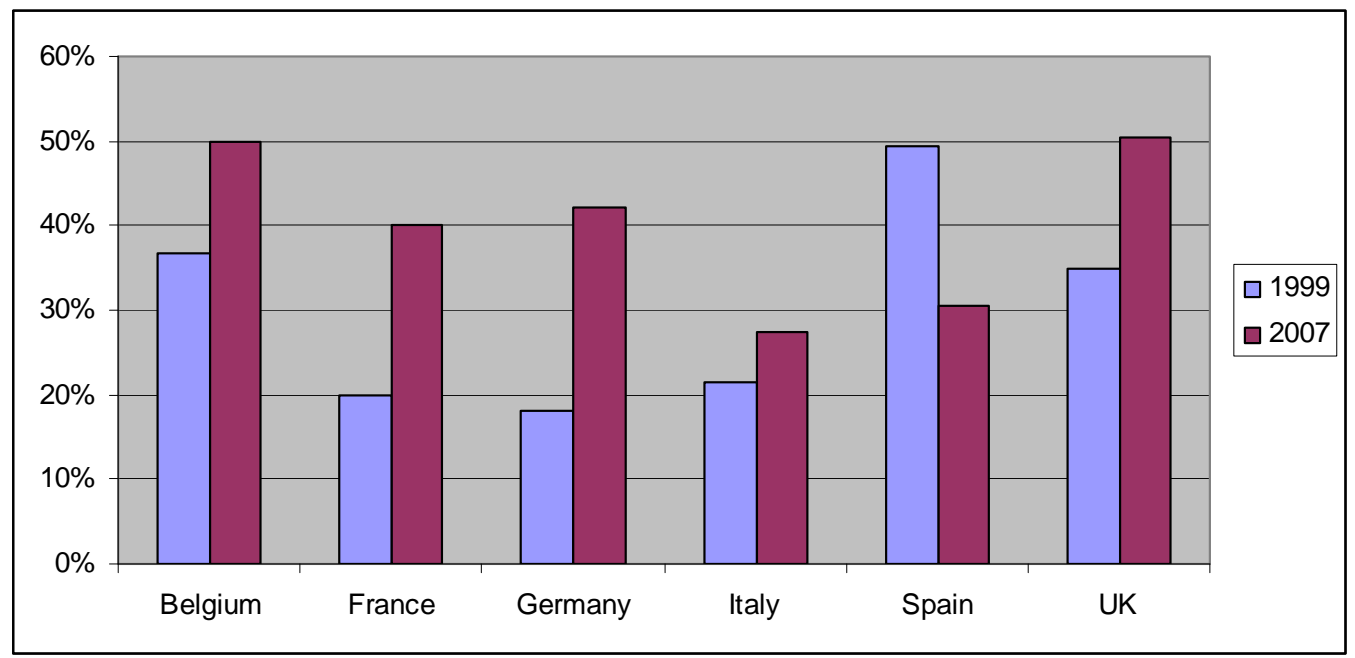

Source: own research

\subsection{Size of the stakes of large foreign shareholders}

Another approach to study the developments of foreign investors looks at the size of the voting block of this investor class. The average voting block size is studied over time and compared with the voting blocks of the national investors.

In all countries but Germany, the average voting block of foreign shareholders decreased between the turn of the century and 2007. In France the average voting block of a foreign shareholder is less than 20 per cent and in Italy, Spain, and the UK less than 15 per cent. In those four countries, the average foreign shareholder is not in a position to control the company, she is not even in the position to successfully block decisions requiring a supermajority approval. In Belgium and Germany the situation is different. The average voting block of a foreign shareholder is sufficient to block significant changes of the company requiring a supermajority approval. Germany, but also Belgium, experienced a significant increase in the number of large foreign stakes, illustrating the significant foreign investors' power.

The second part of the figure contains the average stakes of "national" large shareholders. In general, the average voting block of national large shareholders remained relatively stable over the last decade. In Belgium and Germany the average voting block decreased with 3 per cent to 4 per cent. Especially in the latter country, the developments of the position of foreign shareholders vis-à-vis the national shareholders are striking. Only in Germany foreign shareholders are - on average more powerful than national shareholders. The Belgian situation is different as the large averages for foreign shareholders are due to the position of Dutch trusts in Belgian listed companies. These Dutch trusts are predominantly used as a specific control vehicle for Belgian family patrimonies. For France and Italy, the converse position of foreign large shareholders as in Germany can be found. In Spain and the 
UK foreign shareholders have similar, though slightly smaller voting blocks than national shareholders.

Figure 5: Evolution of the average voting block of large foreign shareholders and other shareholders

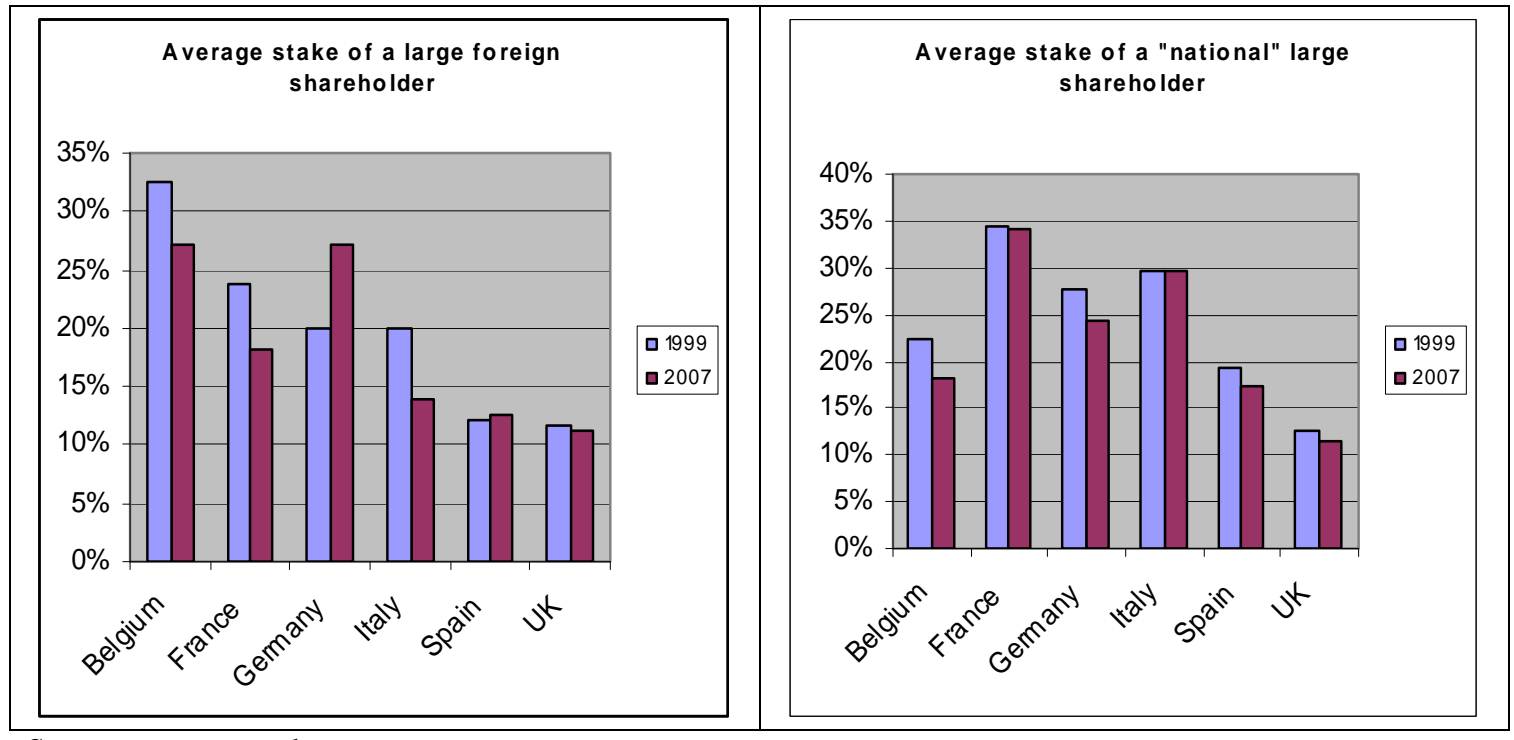

Source: own research

Different investor classes can have different investment policies. Figure 6 presents the average voting blocks of the most common foreign investor classes. In 1999 it was common that foreign non financial companies had large, often de facto controlling voting blocks in Italy, France, Belgium, and Spain and a blocking minority in Germany. Conversely, foreign investment funds, insurance companies and banks only acquired - on average - smaller voting blocks of less than 10 per cent in all countries. ${ }^{13}$ Foreign individuals generally acquired relatively large blocks in Belgium, Germany and the UK, but small blocks in Spain.

The investment policy of investment funds, insurance companies and banks vis-à-vis foreign countries was not adjusted. The average voting block of these types of shareholder classes remained under the threshold of 10 per cent in all countries. There is one exception. Via subsidiaries three banks had acquired a majority voting block in three German companies. These controlling voting blocks increased the average of foreign banks to almost 20 per cent of the voting rights.

For the other classes of foreign investors there are a number of opposite developments. Non-financial companies acquired larger, de facto voting blocks in France, Germany and Belgium. This development should be read together with the significant increase in the number of voting blocks in hands of foreign non-financial companies in Germany and the opposite development in France. Somewhat exaggerating we can say that Germany became a country of subsidiaries, similar to Belgium. In Italy the average voting block of this shareholder class significantly dropped and was only slightly higher than the average block in the UK. Foreign

13 For these classes of shareholders the averages are only provided if there are at least four observations. 
individual investors also behave differently in different countries. Whereas the absolute numbers of foreign individual investors remain modest, this type of investor hold or acquired a de facto controlling voting block in Belgium and Germany, but must be considered as a pure financial investor in Italy and Spain with average voting blocks of less than 8 per cent. In the UK, overseas individual investors seem to develop a similar policy as in Germany and Belgium: with an average of 25 per cent of the voting rights which is more than twice the average size of the voting block of the other foreign investor classes in the UK, this type of investor seeks de facto control over the UK company.

Finally, the new types of investors, foreign private equity funds and foreign hedge funds not only acquired a significant number of blocks in Germany and France, the average voting block must be considered as higher than can be expected from a pure financial investment perspective. In both countries the average voting block is almost 25 per cent.

Figure 6: Evolution of the average voting block of different classes of large foreign shareholders

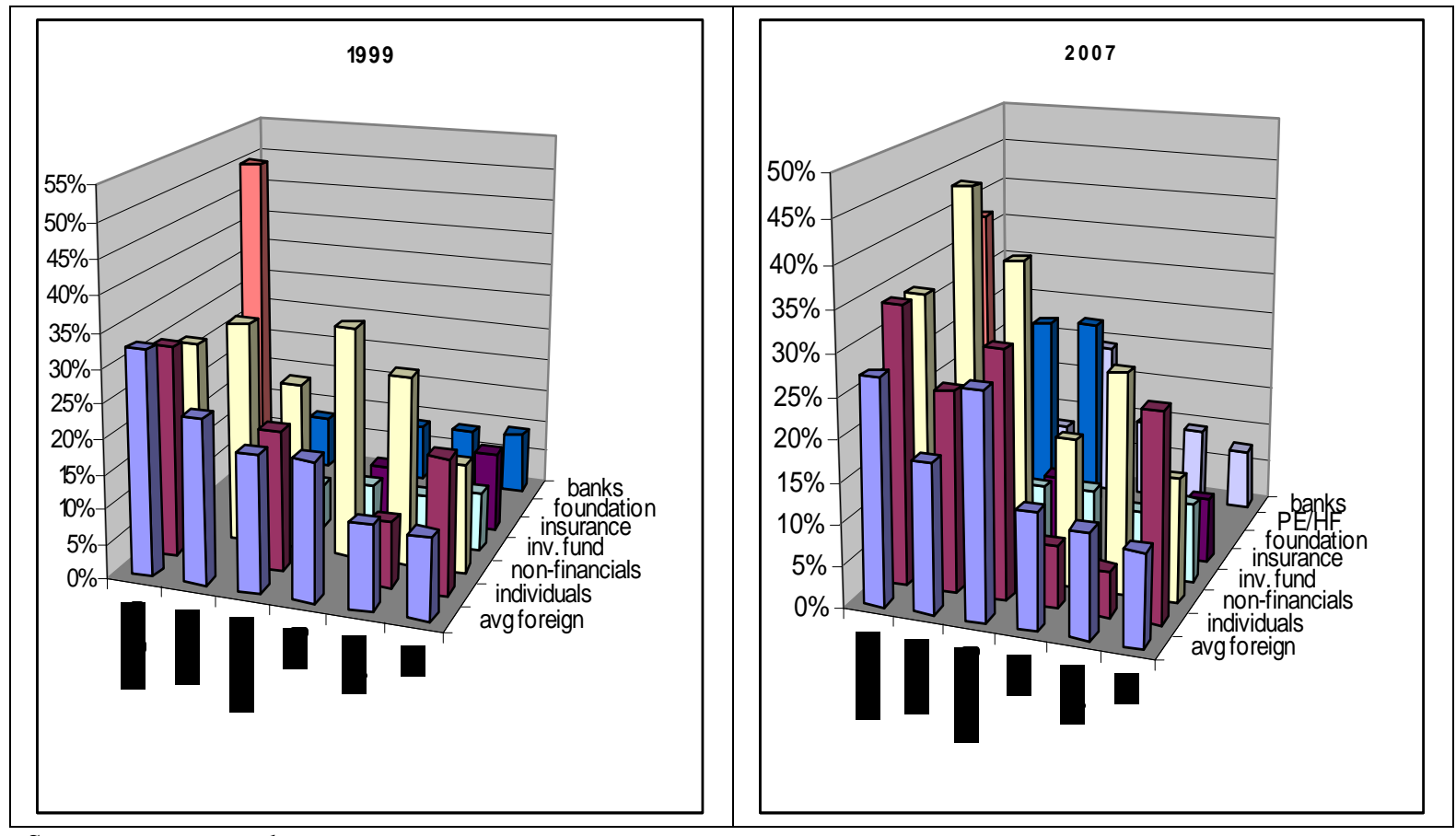

Source: own research

In continental Europe, the position of the largest shareholder is pivotal. ${ }^{14}$ Figure 7 provides information on the position of the foreign shareholder as largest and de facto or de iure controlling shareholder. A de facto controlling foreign shareholder holds a voting block above the mandatory bid threshold and a de iure controlling foreign shareholder is a simple majority shareholder. In 1999, a significant portion of 20 per cent to 30 per cent of the Belgian, Spanish and British companies had a foreign

$14 \quad$ For an analysis see C. Van der Elst, Shareholder Mobility in Five European Countries, ECGI Law Working Paper No. 104/2008. 
shareholder as largest shareholder. Only in Belgium the large majority of these foreign shareholders controlled the company. In France, Germany and Italy less than 10 per cent of the companies had a foreign shareholder as largest shareholder. German companies were in less than 5 per cent of the cases controlled by a foreign shareholder. Eight years later, the pattern altered significantly. In Germany more than 25 per cent of the companies experienced a foreign shareholder as their largest shareholder and in France almost one out of every five companies. The number of de iure by foreign shareholders controlled German companies even overclassed the Belgian number. Equally in Belgium and in the UK the number of largest foreign shareholder increased whereas the number dropped in Italy and Spain. In Belgium, a large number of companies are de facto controlled by a foreign shareholder. The number soared to almost 20 per cent in 2007. While Italy is known for its highest concentration of ownership, it has the lowest number of foreign controlled companies.

Figure 7: Evolution of the number of companies with a foreign shareholder as largest, de facto or de iure controlling shareholder

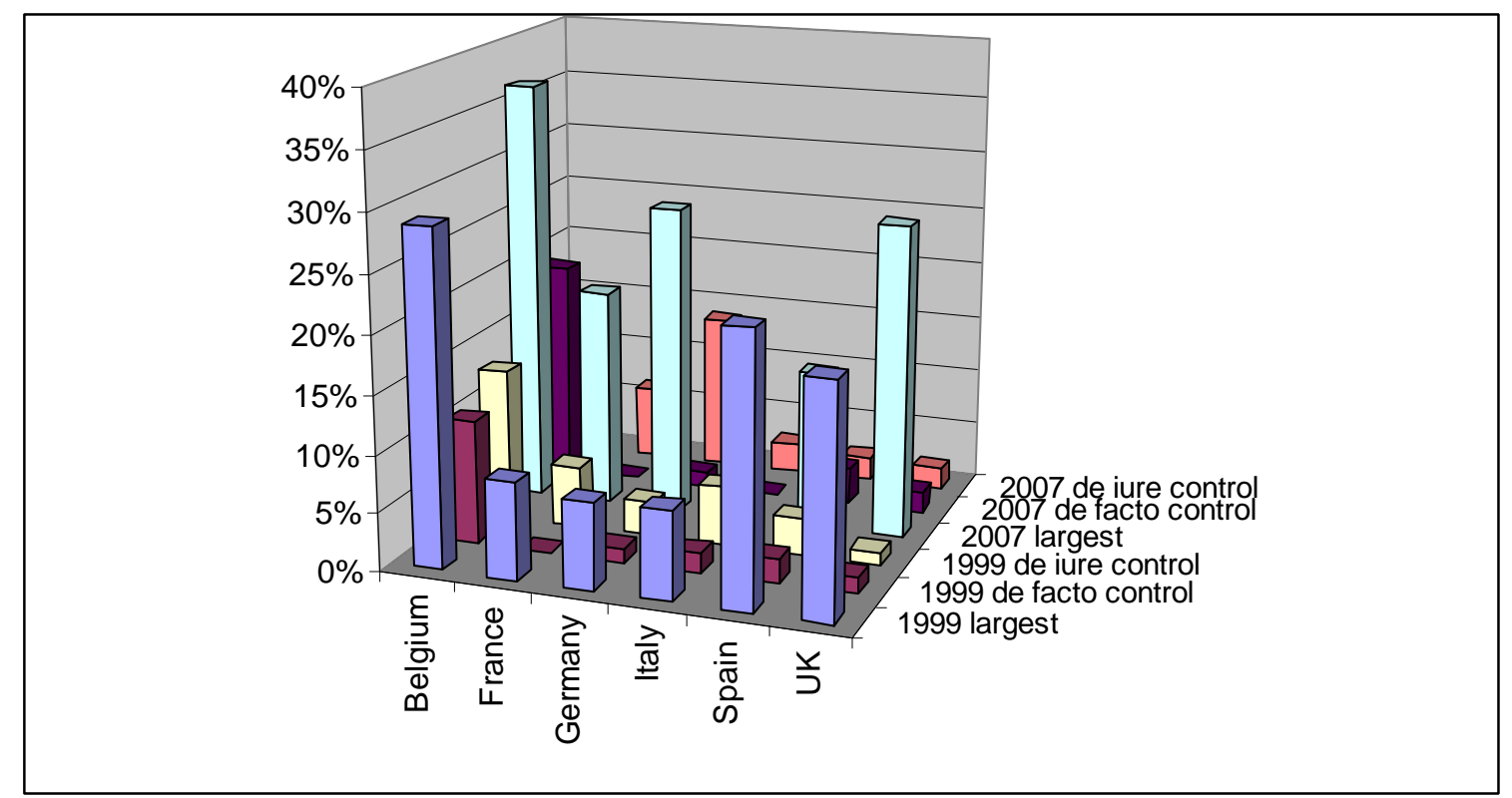

Source: own research

In Figure 8 we further investigated the development of the position of the largest "national" shareholder and the largest "foreign" shareholder. ${ }^{15}$ In most countries the largest national shareholder did not alter its voting block significantly. In Italy, Spain and the UK the difference in the voting block of the largest shareholder was less than 1 per cent between 1999 and 2007, in France 2,5 per cent, in Germany less than 4 per cent and in Belgium 5 per cent. It must be noted that the countries where the decrease in ownership concentration was the largest, also where the countries were the

15 It should be stressed that only stakes that exceed the threshold of 5 per cent of the voting rights have been taken in this analysis. Companies with a widely dispersed ownership structure without shareholders passing this threshold of 5 per cent have been excluded. In all countries in the study less than 7 per cent of the companies belong to this "Berle and Means" type of companies. 
shareholder rights index significantly increased over the period between 1997 and 2005.

The voting block of the largest foreign shareholder developed in an opposite direction in Germany and the variation is of a different magnitude in France, Italy, and Spain. In Germany the largest foreign shareholder has on average a nearly absolute control block. In France foreign shareholders have abandoned this position. In Spain the largest foreign shareholder significantly increased its position and in Italy the largest foreign shareholder significantly decreased its position. In the UK and Belgium the positions did not significantly change. However the largest foreign shareholder in Belgium has a larger voting block than national shareholders, whilst the converse situation can be found in the UK.

Figure 8: Average voting block of the largest "national" shareholder and the largest foreign shareholder

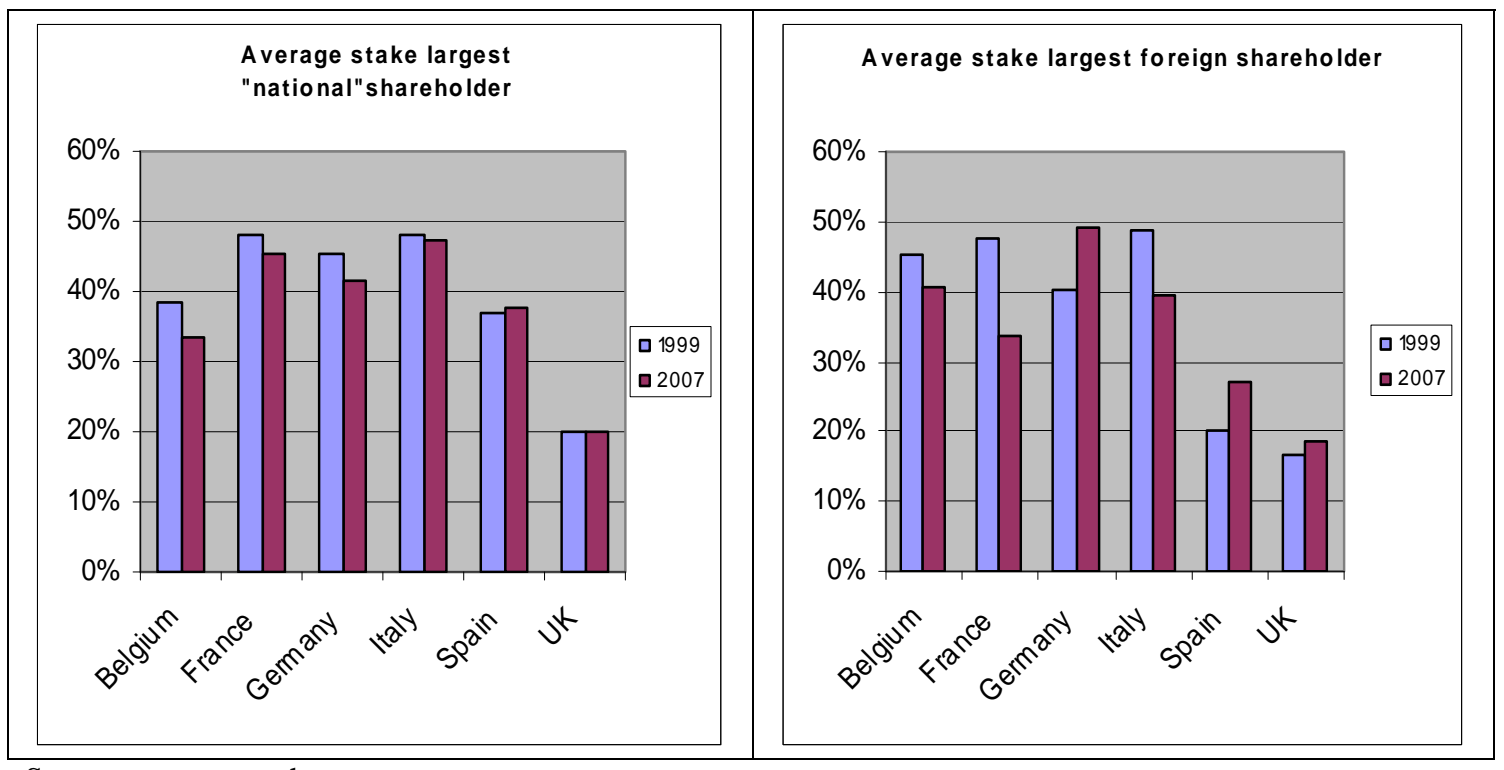

Source: own research

\section{Ownership from a Portfolio Approach}

Ownership can be studied in another dimension. Ownership structures can be identified by summing the total value of the shares in hands of a specified shareholder class related to the total market capitalisation in a specific country. In most countries, a relatively small number of companies represent a large part of the total market value of the "national" stock exchange. Hence this method reflects and emphasizes the ownership structure of "blue chips". FESE regularly studies the portfolio position of different types of the shareholders. Figure 9 provides an overview of the market value of the shares of stock exchange listed companies in hands of foreign shareholders. In all countries, with the exception of Italy, the importance of foreign shareholders moderately increased. Overall, in the UK, France, Belgium and Spain between 35 per cent and 40 per cent of the market value of the companies are in hands of foreigners. 
In Italy and Germany the importance of foreign shareholders is significantly lower with levels of approximately 20 per cent in Germany and only 15 per cent in Italy. In light of the previous findings it can be assumed that in Spain foreign shareholders hold a significant part of the smaller stakes in listed companies, whilst in Germany foreign shareholders have acquired many large stakes. Foreign shareholders seem to be prudent vis-à-vis investments in Italian companies. In Belgium, France and the UK foreign investors invest equally in large and small shareholder stakes.

Figure 9: Market value of stock exchange listed companies in hands of foreign shareholders (1999-2007)

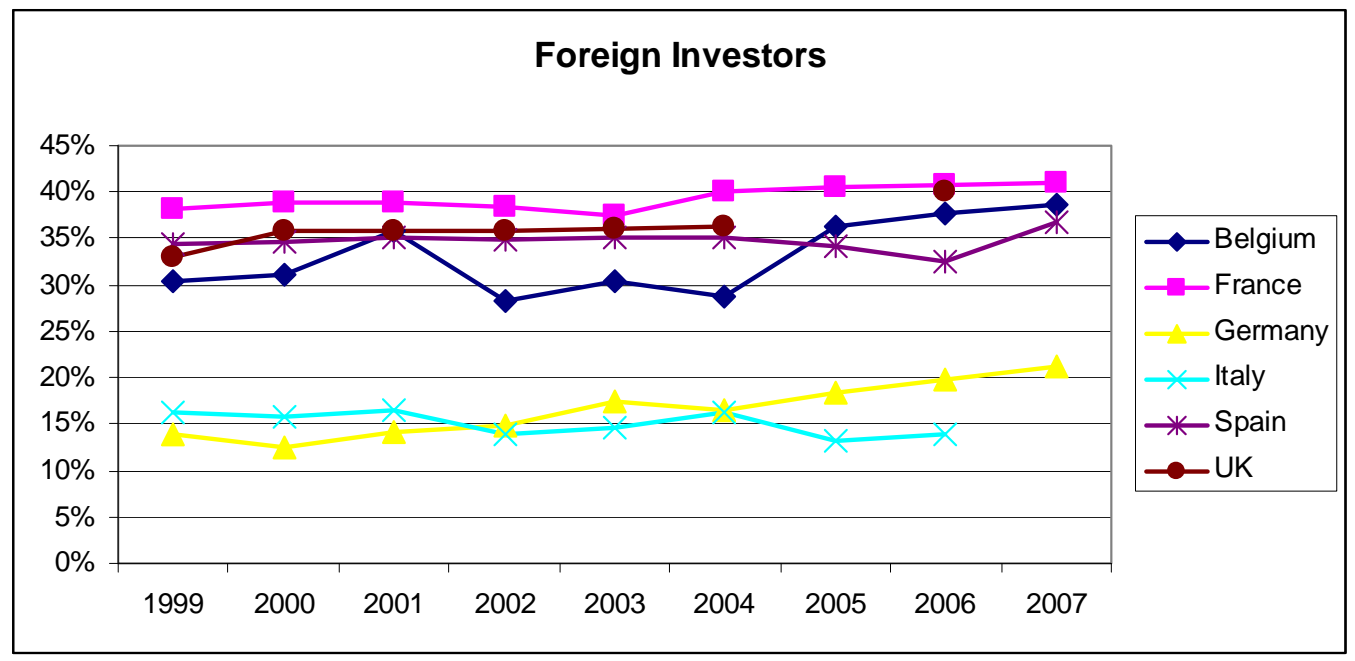

Source: FESE, Share Ownership Structure in Europe, Brussel, December 2008.

\section{Conclusion}

Shareholder rights received considerable attention both from a political and a scientific perspective. It resulted in a better understanding of the role and importance of shareholders in corporate governance over the last decades. In many countries shareholders were offered more rights against "inappropriate" behaviour of other corporate constituents or colleagues. Whether these developments result in more market participation and deeper and more liquid markets, as argued in law and finance theory, remains an open question. For a large sample of European listed companies we revealed part of the answer: we analysed the evolution of the investment behaviour of foreign shareholders in a large sample of European companies between 1999 and 2007. We considered that this type of shareholder is more sensitive to (changes in) shareholder rights than "national" shareholder classes.

A steadily growing number of 15 to 30 per cent of all large stakes belong to foreign shareholders. One out of four to half of the companies in the different European countries have a large foreign shareholder in their shareholder circle. The importance of foreign non-financial companies as large shareholders is declining in all countries but Germany and foreign investment funds grow in number of large stakes except in Spain. Spain experienced also a sharp decline in the number of large foreign bank stakes. The average voting block of a foreign shareholder decreased in all countries but in Germany. This development resulted in Germany being the country with the 
largest number of de iure foreign controlled companies of all countries in 2007. Foreign hedge fund and private equity funds became important foreign shareholders in France and Germany, whereas they are hardly present in the other countries.

The results in this paper show that the hypothesis of a straightforward inverse linear relationship between shareholder rights and ownership concentration is not confirmed. The significant increase in the number of shareholder rights in Belgium, France, and Germany, did not result in a significant decrease in (foreign) shareholder concentration levels: foreign non-financial companies increased their voting position up to de facto controlling voting blocks in France and Germany. Neither did the insignificant changes in Italy, Spain and the UK resulted in a status quo in these countries: in Italy the average voting block of foreign shareholders dropped and foreign non-financial companies relinquished their de facto controlling voting blocks, whilst foreign individuals of British companies increased their voting block.

Other features drive the development of ownership structures. These factors can be of a legal nature: in Europe, UCITS may not invest more than 5\% of its assets in transferable securities or money market instruments issued by the same body and are prohibited to acquire any shares carrying voting rights which would enable it to exercise a significant influence over the management of an issuing body. A feature can also be shareholder specific: some Belgian families control a listed company via a Dutch trust ("administratiekantoor") allowing the separation of financial benefits and the controlling power.

Figure 10: Voting block of the foreign largest shareholder in 2007

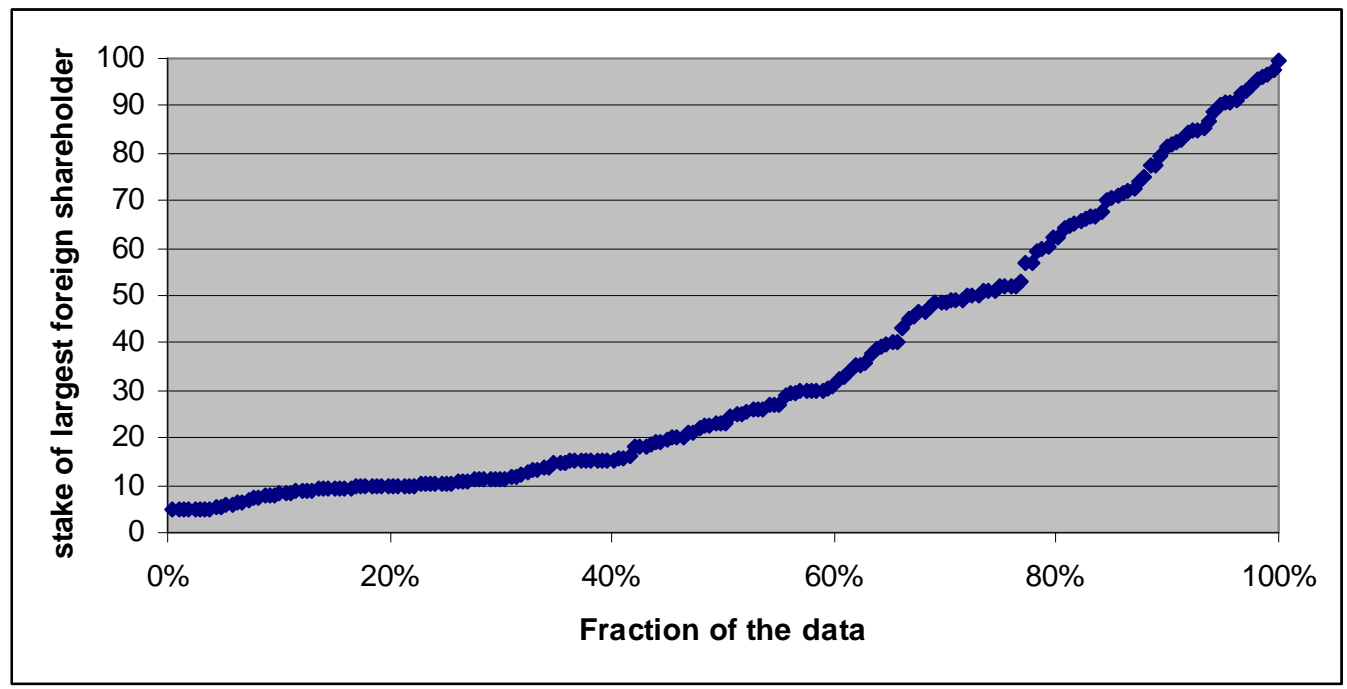

Source: own research

There are other indications that the relationship between shareholder rights and ownership patterns are not straightforward. Many shareholder rights are related to a specific threshold: 5 per cent is allowed to call a general meeting, 25 per cent blocks important decisions, 30 per cent requires the mandatory bid offer, 50 per cent controls the general meeting, 75 per cent changes the articles of association and 95 per cent 
squeezes the minority shareholders. ${ }^{16}$ Only a small number of these thresholds seem to be influential determinants for shareholder voting block acquisitions. Figure 10 presents the voting block of the foreign shareholder of all companies in the sample if this shareholder is the largest shareholder. Only at the level of 30 per cent, the mandatory bid threshold in five of the six countries, the line is flatter. Other thresholds are not clearly identifiable. ${ }^{17}$

These results do not reject any kind of relationship between shareholder rights and investment policies. First, the leximetric approach is still under construction. Not all rights have been addressed. Next, shareholder rights are considered of equal importance. It is more than likely that some rights matter more than other rights. Third, in a time frame of one decade the variability of both shareholder rights and ownership structures is relatively limited. All industrialised countries in the sample offer already a significant number of shareholder rights. These rights seem to be sufficient to appeal foreign shareholders. A larger sample of countries were the development of shareholder rights is more or less advanced and more longitudinal studies are required to reveal more precisely the relationships between (corporate and securities) law and the capital market.

$16 \quad$ These thresholds are not universal but many countries adopted these ceilings.

17 The line is somewhat flatter around the threshold of 50 per cent but this is the case at both sides of the threshold. 